\title{
Canada and the Use of Force: Reclaiming Human Security
}

\author{
Jutta Brunnée and Stephen J. Toope
}

Version Publisher's version

Citation Brunnée, Jutta and Toope, Stephen J., Canada and the Use of Force: (published version) Reclaiming Human Security (2004). International Journal (Canadian Institute of International Affairs), Vol. 59, pp. 247-260, 2004.

Publisher's Statement Brunnée, Jutta and Toope, Stephen J., Canada and the Use of Force: Reclaiming Human Security (2004). International Journal (Canadian Institute of International Affairs), Vol. 59, pp. 247-260, 2004. Copyright (C [2004]. Reprinted by permission of SAGE Publications. https://doi.org/10.2307/40203925

How to cite TSpace items

Always cite the published version, so the author(s) will receive recognition through services that track citation counts, e.g. Scopus. If you need to cite the page number of the author manuscript from TSpace because you cannot access the published version, then cite the TSpace version in addition to the published version using the permanent URI (handle) found on the record page.

This article was made openly accessible by $U$ of $T$ Faculty. Please tell us how this access benefits you. Your story matters. 


\section{JUTTA BRUNNÉE \& \\ STEPHEN J. TOOPE}

\section{Canada and the use of force}

\section{Redaiming human security}

$\mathbf{T}$

HE EVENTS OF 11 SEPTEM BER 2001 PRO PELLED theissue of global terrorism to the top of the international agenda, and prompted dramatic shifts in international political dynamics. Although thereis wide agree ment that the world is facing complex security challenges, a harsh debate has opened up over the appropriate responses. Building on the existing rhetoric of the "clash of civilizations," ${ }^{1}$ this debate was initially cast as one between thewest and I slam and emerged immediately upon the invasion of Afghanistan. W hat is now apparent is that fissures have broken open within western culture that may be equally wide. ${ }^{2} T$ he most pointed disagreements pit the political and cultural elites of "O Id

Jutta Brunnée isProfessor of Law and M etcalf Chair in Environmental Law at the U niversity of T oronto, and Stephen J. T oope is President of the PierreElliott T rudeau Foundation and Professor of Law at M CG ill U niversity (on leave). The views expressed should not be attributed to the Foundati on. The authors benefitted from the excellent research assistance of Sarah Perkins, Robert Rastorp and Sean Rehaag. In September 2003, the Canadian Centrefor Foreign Policy D evelopment of DFAIT funded a workshop that considered a draft of this paper. The authorsthank all the workshop participants and Kent Roach for their comments. This essay is part of a larger research project funded by the Social Science and H umanities Research Council of Canada.

1 Samuel P. Huntington, “The Clash of Civilisations?" Foreign Affairs 72, no. 3 (Summer 1993): 22.

2 See Dominique Mosi, “Whither the West," Foreign Affairs 82, no. 6 (November/December 2003): 67, which argues that November 9, 1989, the fall of the Berlin Wall, marked the end of the "old West," and the beginning of a dissonance between European and American interests; Jed Rubenfeld, "The Two World Orders," Wilson Quarterly (Autumn 2003): 22, which argues that two fundamentally different understandings of the international legal order are espoused by Europeans and Americans, respectively. 
Europe" against those of the U nited States, ${ }^{3}$ but the phenomenon is broader, setting traditional allies such as the U nited States and $C$ anada in opposition to each other. ${ }^{4} \mathrm{M}$ oreover, within western states, political divisions over the war in Iraq accentuated a widening chasm between "liberal" and "neo-conservative" forces. ${ }^{5}$

Around the globe, the debate over responses to global terrorism has raised hard issues concerning the interplay of security concerns, human rights, democratic governance and the use of force. W ithin the US, influential voices are articulating a merging of these concerns in a way that fundamentally challenges the concepts of state sovereignty, non-intervention and political independence. ${ }^{6}$ Fear seems to be the driving force for normative change. This fear is accentuated by the now-recognized vulnerability of the infrastructure of modern society, and by uncertainty as to who will be targeted and by what horrific means of attack. All values are becoming subsumed within the value of security, justifying the use of force against other states in an everbroadening set of circumstances. Canada is particularly implicated in these developmentsfor they threaten to subvert thegoals of the human

3 "Rumsfeld dismisses 'old Europe' defiance on Iraq," CBC News, www.cbc.ca/stories/2003/01/23/rumsfeldo30123 (accessed 23 October 2003). "Philosophizing about Europe's Rebirth" Deutsche Welle, www.dw-world.de/english/o,3367,1433 A_884292_1_A,oo.html (accessed 23 October 2003) discusses the recent interventions of Jürgen Habermas and Jacques Derrida.

4 See Timothy Garton Ash, “Are You With Us? Are we Against You?” New York Times (30 May 2003), www.aei.org/research/nai/news/newsID.17669,projectID.11/ news_detail.asp (accessed 21 August 2003).

5 See, for example, Lloyd Axworthy, "Affirming our duty to protect," National Post (10 September 2003); Allan Gotlieb, "Canada must return to its 'golden age' of diplomacy," National Post (10 September 2003).

6 See Allen Buchanan \& Robert O. Keohane, "The Preventive Use of Force: A Cosmopolitan Institutional Perspective," (2003), www.duke.edu/ pfeaver/ BuchananKeohanepaper.pdf (accessed 23 October 2003). The authors argue the need to develop international law and institutional arrangements for "cosmopolitan accountability" regarding the use of preventive force to protect human rights. Also various contributions to J.L. Holzgrefe \& Robert 0 . Keohane (eds.), Humanitarian Intervention: Ethical, Legal and Political Dilemmas (Cambridge: Cambridge U. Press, 2003); Anne-Marie Slaughter, "Präzisionswaffe Völkerrecht: Die Demokratien müssen sich verbünden - zu einer neuen Kraft innerhalb der Un," Die Zeit 28, no. 3 (July 2003), www.zeit.de/2003/28/Essay_Slaughter (accessed 21 August 2003); Anne-Marie Slaughter, "Notes from the President: A Fork in the Road," American Society of International Law Newsletter 1 (September/October 2003), 4, which suggests a "caucus of democracies" or other "alternative fora of discussion in the un, and perhaps ultimately of legitimation for action taken by some sub-set of UN actors." 
security agenda that has defined recent $C$ anadian foreign policy. The basic premise of that agenda has been that security concerns should be evaluated primarily on the basis of the well-being of people rather than the physical security of states. ' In the vast majority of cases, the promotion of human security calls not for the resort to military force but for measures that build social and economic capital and improve local governance. In the face of recent developments, C anada must reclaim, and probably recast, the human security agenda. It should al so resist arguments for excessive reliance on the use of force. M oreover, caution is warranted where human security arguments are deployed to bolster defensive considerations that do not actually rise to a level justifying the use of armed force under international law.

\section{THE GLOBAL POLICY ARENA}

The shifts in policy and perception that are taking place are transforming the global political context, but thetrajectory of change is not clear. "Clashes of civilization," 8 "power and weakness," new Rome ${ }^{10}$ are not simply circumstances of fact. They are also social constructions, built in large part upon ideas and norms. ${ }^{11}$ States continue to define their relationships with each other through political choices that are influenced by prevailing norms. That is why the promotion of norms matters in international relations. Canada must be active in the reinforcement of valuable normative frameworks, and must promote new norms where circumstances so demand. To play these roles effectively, $C$ anada must concern itself with the cultivation of its persuasive power. ${ }^{12}$

$M$ any commentators argue that September 11th, and the subsequent invasions of Afghanistan and Iraq, reveal the need for states,

\footnotetext{
7 See Lloyd Axworthy, "Human Security and Global Governance: Putting People First," Global Governance 7, no. 1 (January 2001), 19.

8 Huntington, "Clash of Civilizations."

9 Robert Kagan, “Power and Weakness," Policy Review 3 (2002): 113.

10 Joseph Nye, "The New Rome Meets the New Barbarians: How America Should Wield Its Power," The Economist (23 March 2002), 24; and Michael Ignatieff, Empire Lite: Nation Building in Bosnia, Kosovo, Afghanistan (Toronto: Penguin Canada, 2003), 3.

11 Alexander Wendt, "Anarchy is What States Make of it: The Social Construction of Power Politics," International Organization 46, no. x (XXX 1992): 391.

12 Greg Foster, “A new kind of 'world power'," Globe and Mail (12 August 2003), A13.
} 
including $\mathrm{C}$ anada, to invest in hard power. ${ }^{13} \mathrm{~W}$ hile greater investment in the security infrastructure does seem justified, it is al so important to stress the limitations of material power revealed by the chaos in "postwar" Iraq, and the loss of trust in, and good will towards, the us in the aftermath of the I raq invasion. In the early days of the Iraq War, the us military asserted that it could project its power simultaneously in two distant theatres of war. ${ }^{14}$ Since then, us military power in I raq has been severely tested, and it is questionable whether the us can even sustain its engagement in this single theatre for the time necessary to accomplish its goals. If anything has been reveal ed since September 11th, it is that material power is itself weak in many circumstances, ${ }^{15}$ and states like $C$ anada need to pay attention to both their hard power assets and to their capacity to influence through persuasive power.

Persuasive power is cultivated in part through the articulation and upholding of normative frameworks, including the framework of international law. Today, we are confronting a bewildering confusion of international legal norms that threatens to undermine constraints on the use of forcein international society. Thisconfusion occurs when attempts are made to collapse legally distinct categories such as human rights, refugee protection, and threats to international peace and security into one super-category of "threat pre-emption," using the other categories simply as examples of dangers that can be invoked to justify action as defensive, rather than aggressive. This phenomenon is apparent in theex post facto justificationsfor thel raq war. ${ }^{16} \mathrm{~T}$ hecontours of the "threat" that demanded responsehave become unclear, and categories of justification are being merged, confused and ultimately disabled.

$\mathrm{N} o$ one would deny that there are linkages amongst humanitarian crises, repressive regimes, collapsing states, terrorism and international

13 See, e.g., David Bercuson, “Restore Canada's Hard Power Assets," National Post (10 September 2003), www.nationalpost.com/commentary/story.html?id $=1 \mathrm{adb} 75 \mathrm{~b} 4-8247-44 \mathrm{e} 7-93$ c2-3ef375aa904b (accessed 23 October 2003).

14 Amy Waldman \& Dexter Filkins, “2 U.S. Fronts: Quick Wars, but Bloody Peace,” New York Times (19 September 2003), A1.

15 We are indebted to Emanuel Adler for conversations that clarified this point. See also Kent Roach, September 11: Consequences for Canada (Montreal \& Kingston: McGill-Queen's University Press, 2003), 198. He suggests that we ask, in the context of the war against terrorism, whether reliance on "hard power" strategies and "the use of military force will actually make us more secure".

16 See, e.g., White House, "Operation Iraqi Freedom" (5 April 2003), www.whitehouse.gov/news/releases/2003/04/20030405.html (accessed 12 June 2003); and Ed Morgan, “Use of force against Iraq is legal," National Post (19 March 2003). 
security threats. Yet neither intelligent policy response nor international law is aided by simply merging all of these issues. Linkages should be carefully considered, but interventions must be justified on grounds that relate to the actual problems that one is seeking to alleviate. Existing legal categories, though in need of some revision, continue to play a necessary role in disciplining our justification for action. Self-defence, threats to international peace and security, and humanitarian intervention remain usefully distinct.

THE GLOBAL LEGAL FRAMEWORK

Existing international law rules limit the right of states to resort to war, asking us to pause and inquire whether war is necessary. The debate over I raq laid bare some failings in these rules. But the need to limit resort to war, and to demand strong justification for the use of force, is as great as ever. Instead, some politicians and commentators undermine these restraints on military force by combining, shifting and reinterpreting a variety of reasons for war. The argument runs that human rights abuses are themselves dangerous to our society, that global terrorism is bred in failing states, and that even a potential weapon of mass destruction programme requires pre-emption. ${ }^{17}$ All these issues are lumped together as a global super-threat, justifying war and placing it beyond challenge. That is exactly why international law requires more specific, testable claims. Is a given war justified as selfdefence? Is a state asserting a right to humanitarian intervention? D oes it claim a threat to international peace and security that would normally require Security $C$ ouncil action?

International law entitles states to defend against actual or imminent attacks. There are no other legally accepted reasons for unilateral resort to military force. Thisframework remains important. Theworld would certainly not be a safer place if international law permitted over 190 individual states to be their own judge and jury on when to use weapons to resolve disputes. Anticipatory self-defence is a necessary complement to the response to armed attack allowed by Article 51 of the UN Charter, as long as it is circumscribed by the well-established requirements of necessity, including imminence and proportionality. ${ }^{18}$

17 See, for example, Ruth Wedgwood, "The Fall of Saddam Hussein: Security Mandates and Preemptive Self-Defense," American Journal of International Law 97, no. x (xxxX2003): 576.

18 See Robert Y. Jennings, “The Caroline and McLeod Cases” (1938) 32 American Journal of International Law 82. 
The idea of threat prevention, as advanced in the us $N$ ational Security Strategy, ${ }_{19}$ is not.

Judging by the developments surrounding the I raq War, states' unilateral rights to self-defence havenot expanded to encompass pre-emptive strikes. In fact, the perceived challenge to the rules on the unilateral use of force by the us prompted others to rally around and reinforce the existing framework. Academic commentators became actively engaged in the normative debate and a large majority argued forcefully that an intervention in Iraq could not bejustified as self-defence. ${ }^{20}$ Governments around the world showed little enthusiasm for the concept of pre-emptive self-defence, and the us government chose not to make I raq the test case for its security strategy doctrine. In its $20 \mathrm{M}$ arch 2003 , letter to the Security C ouncil, theU nited States did not rely primarily upon self-defence, but rather claimed that its military measures were authorized under a series of C ouncil resolutions from 1990. ${ }^{21}$ It may well be that the security strategy, advancing a sweeping pre-emptive strike doctrine, reflects the high-water mark of us self-defence rhetoric, and that theactual legal justifications for the Iraq invasion are indicative of a shifting tide.

International institutions, most notably the $\mathrm{U}$ nited $\mathrm{N}$ ations and its Security Council, have not become irrelevant. They provide an indispensable forum for the mutual engagement of states, a forum in which processes of deliberation and justification can take place. $\mathrm{N}$ otwithstanding the widespread dissatisfaction with its performance over theyears, the Security Council does seem possessed of a uniqueand enduring - ability to lend legitimacy to international action, including the use of force under Chapter vII of the UN Charter.

19 USA, The National Security Strategy of the United States of America (September 2002), www.whitehouse.gov/nsc/nss.pdf (accessed 8 June 2003).

20 See media declarations by leading internationalists in Australia, Canada, and the us. "Howard must not involve us in an illegal war," The Age (26 February 2003), www.theage.com.au/articles/2003/02/25/1046064031296.html (accessed 11 March 2003); "Military Action in Iraq Without Security Council Authorization Would be Illegal," Open Letter signed by 31Canadian Professors of International Law, (17 March 2003) www.sdiq.org (accessed 18 June 2003); and Peter Slevin, "Legality of War Is A Matter of Debate - Many Scholars Doubt Assertion by Bush," Washington Post (18 March 2003), www.commondreams.org/headlines03/0318-05.htm (accessed 3 June 2003).

21 John D. Negroponte, “ Letter dated 20 March 2003 from the Permanent Representative of the United States of America to the United Nations addressed to the President of the Security Council," (20 March 2003), UN Doc. S/2003/351. 
0 utside the real $m$ of self-defence, there is no plausible alternativeto the collective legitimization of the use of force through the Security Council. The General Assembly lacks an appropriate sense of responsibility in actions relating to the use of force because its decision-making authority is too diffuse. Ad hoc "coalitions of the willing" typically lack neutrality and therefore have no legitimacy. ${ }^{22}$ Suggestions that a more permanent "coalition of liberal democratic states" might serve as a supplementary decision-making authority to authorize the use of force when the Security Council is paralysed are highly problematic. ${ }^{23}$ $D$ eveloping states have been fighting for years to destroy the outmoded notion that there is a core group of "civilized states" that provides the sole model to emulate if a state seeks international credibility. In addition, the idea completely undermines the cosmopolitan aspirations of international law, and the diversity of its sources. Were the idea to be implemented through the banding together of a coalition of democratic states, it would only serve to further poison international relations.

The frustration and tension that arose during Security Council debates over I raq may serve as an impetus for institutional change at the UN . It is in part this hope that animates K ofi Annan's recent initiative, the creation of a blue ribbon taskforce to recommend "clear and practical measures for ensuring effective collective action" to deal with "today's global threats" and "future challenges to peace and security." ${ }^{24}$ $\mathrm{N}$ onetheless, reform will behighly problematic and may proveelusive. ${ }^{25}$

22 It might be objected that NATO's intervention in Kosovo is an example of a selfappointed coalition achieving a degree of legitimacy. However, the Kosovo intervention can be distinguished from the invasion of Iraq on a number of counts. First, in Kosovo there was credible evidence of actions amounting to a continuing, even escalating, genocide. Secondly, the inability of the Security Council to act resulted from the threatened veto of a single state with a direct interest in the dispute, and not from a broader resistance to the proposed use of force. Thirdly, the NATO intervention took place after an extended and intense multilateral effort to broker a peaceful settlement. See also Tom Farer, "The Prospect for International Law and Order in the Wake of Iraq," American Journal of International Law 97, no. X (XXX 2003): 625-626.

23 See, for example, Slaughter, "Präzisionswaffe Völkerrecht," and "Fork in the Road."

24 Kofi Annan, Address to the United Nations General Assembly (23 September 2003); www.un.org/apps/sg/sgstats.asp (accessed 23 September 2003). See also UN Press Release SG/A/857, "Secretary General Names High-Level Panel to Study Global Security Threats, and Recommend Necessary Changes," (4 November 2003); www.un.org/News/Press/docs/2003/sga857.doc.htm (accessed 25 November 2003).

25 David Malone, “Don’t hold your breath,” Globe and Mail (22 September 2003), A15. 
Even if institutional reform is impossible, there is an urgent need to address the sense of failure engendered by Security C ouncil inaction in theface of massivehumanitarian crises, such as in Bosnia, Rwanda and Congo. The Security Council's legitimacy has suffered in part because of its inability to balance constraints on the use of force and the need to mobilize intervention when urgently needed. ${ }^{26} \mathrm{~T}$ he time is ripe to develop criteria to guide the Council in making decisions on the collective use of force to forestall humanitarian disaster. Even absent reforms to the Council's membership and decision-making processes, such guidelines could make an important contribution to restoring the Council's legitimacy and effectiveness. At the same time, clarifying the parameters of humanitarian intervention will be crucial to resisting a blending of humanitarian and security justifications that could eviscerate the constraints on the unilateral use of force.

\section{WANTED: CANADIAN LEADERSHIP}

Because the USA is perceived with fear by allies as well as foes, its persuasiveness in international affairs is diminished. To the extent that us persuasive power is declining, this opens up space for other actors, including $C$ anada, to exert greater influence. But it is not enough simply to recognize a space to act and influence. $O$ pportunities must actually be seized when they present themselves. A troubling, but probably accurate, reading of events after 11 September 2001 is that forces seeking to reconfigure global politics used the shock of terrorist attacks on American soil to set a new agenda for us policy in relation to Afghanistan, Iraq, the M iddle East, and more broadly, the unilateral use of force. ${ }^{27}$ If $\mathrm{C}$ anada is to press its own agenda, in cooperation with other like-minded states, it must be prepared to exploit the next crisis in a similar fashion. ${ }^{28}$ If $\mathrm{C}$ anada seeks to resist normative claims to a unilateral right to the preventive use of force, it must help to articulate a cogent alternative to address threats from Iran and $\mathrm{N}$ orth Korea, to take but two examples of potential crises.

The current orientations of the foreign policy of the us administration do not necessarily represent a fundamental, or even long-term,

26 See, for example, Michael Barnett, Eyewitness to a Genocide: The United Nations and Rwanda (Ithaca: Cornell University Press, 2002).

27 Thomas M. Franck, "What Happens Now? The United Nations After Iraq," American Journal of International Law 97, no. X (XXX 2003), 610.

28 We are indebted to Richard Price for conversations that clarified this point. 
shift in American attitudes towards global issues. Canada should not over-react to the challenges presented by the present constellation of US interests or to the attitudes of the Bush administration. C anada must maintain close political, cultural and economic ties with the $U$ nited States. The us is not only the elephant next door, whose every twitch is felt as an earthquake, but it is probably the country that $C$ anadians are closest to in terms of values, although there are suggestions that this may be changing. ${ }^{29} \mathrm{C}$ onnections with the us are not based solely on need; they reflect desire and are based upon genuine affection as well. At a purely pragmatic level, $C$ anada and the U nited States are bound by a common border. $C$ anada's interest in maintaining the relative openness of that border to facilitate trade is acute.

C anada needs to demonstrate the sensitivity of a close friend to the fears that currently drive us foreign policy. C anada must continue to pursue a strong policy of support for the fight against global terrorism. It must also cooperate as closely as possible on border security issues, while preserving the autonomy of $\mathrm{C}$ anadian law and our commitment to the values of a relatively open, multicultural society. ${ }^{30} \mathrm{C}$ anada should not contribute to the re-invention of a "balance of power" with Europe or others serving as explicit counter-weights to us influence.

O n many issues, and rightly or wrongly, C anada is seen to be a mere appendage of the us. Indeed, it is not apparent that even C anada's most pointed recent disagreement with the us- over the invasion of I raqhas registered with the general public in other regions of the world. ${ }^{31}$ In part, the continuing perception of a lack of independence was fed by the $C$ anadian government's equivocation in the weeks leading up to the invasion of Iraq, when it seemed to want to keep all its options open. Although this approach is often sensible, it became counterproductive because once a final decision was made, all parties to the debate were let down. The us was not being supported by a close ally. Yet $C$ anada had madeno clear normativestatement on the unilateral use of force because it had indicated that it just might support the us until the very last moment. To the extent that the us is widely distrusted,

29 Michael Adams, The United States, Canada and the Myth of Converging Values (Toronto: Penguin Canada, 2003).

30 See, for example, Roach, September 11: Consequences for Canada, 136-141. $31 \mathrm{~A}$ review of world press, conducted in August 2003, yielded articles that mentioned Canada's failure to join the "coalition of the willing" as a side note to the general lack of world support for the US action (on file with authors). 
Canada suffers collateral damage. This perception must also be addressed actively in Canadian foreign policy.

$C$ anada's persuasive power is founded in part upon its reputation for committed multilateralism, including significant engagement with the developing world, and in part upon attractive features that mark our society. In the words of a senior C anadian diplomat, "W hen we speak in the Security Council, our influence comes from who we are domestically, and what we stand for internationally." ${ }^{32}$ Although a commitment to multilateralism cannot mean that $C$ anada must defer to every agenda set by the $U$ nited $\mathrm{N}$ ations, it does mean that $\mathrm{C}$ anada must continue to recognize that its own ability to persuade depends in large measure upon its reputation as an engaged and cooperative international actor. It also depends upon a widespread perception that Canada's is an admirable society.

As a country of immigration, $C$ anada has fostered a workable multicultural society, while managing over the last century to accommodate the sometimes differing visions of the two "founding" European communities. Of course, Canada continues to grapple with its own failures, notably in relations with the first nations and in addressing social and economic inequality. $N$ onetheless, $C$ anada is widely viewed as tolerant of diversity in matters of language, culture, race and sexuality. C ountries tend to have political influencedisproportionate to their military and economic power when they incorporate widely attractive causes such as development assistance or peacekeeping into their national identity, and when they project values that inspire people around the globe. ${ }^{33}$ Because C anadians seem to value an outward-looking, multilateralist identity for the country, success as an effective international actor bolsters C anadians' self-image.

C anada's generally positive reputation, and attendant influence, needs to be continually cultivated and earned. In recent years, this reputation has become frayed. The erosion of $\mathrm{C}$ anada's foreign aid budget throughout the 1990s was widely noted, as was its inability to field substantial peacekeeping forces. Canadian business, with a few notable exceptions, seems uninterested in foreign investments outside the U nited States. After the completion of the Landmines C onvention 
and the Rome Statute of the International C riminal C ourt, Canada seemed to lack an international agenda. W hat is more, the $C$ anadian government finds it difficult to coordinate the various assets that should bebrought to bear in international relations. Foreign policy, aid policy and defence policy are not well aligned. For example, the recent decision of CIDA, the Canadian International D evelopment Agency, to focus $C$ anadian aid on nine countries, ${ }^{34}$ although welcome in terms of long-overdue priority setting, is strange in that the countries selected are not obviously central to Canadian interests or to current, or even foreseeable, foreign policy imperatives. ${ }^{35}$ Similarly, it is well known that $C$ anada's defence forces are simply not strong enough to fulfill the various missions that might usefully be undertaken in support of an engaged diplomacy. M oreover, the capacity to fight and the capacity to keep the peace must be balanced; training for each role is quite distinct, ${ }^{36}$ as us forces have discovered to their disquiet.

Canada's only obvious foreign policy framework today is a continuing commitment to the "human security" agenda first promoted by Foreign M inister Lloyd Axworthy in the 1990s. I ronically, that agenda is now being co-opted and used for purposes quite distinct from those that the $C$ anadian government might have imagined.

The current articulation of $C$ anada's human security agenda emphasizes that:

[S]ecurity istruly indivisible: it cannot be achieved at the expense of others, and indeed we ignore the insecurity of others at our expense. Growing connections between regions of the world make it clear that not just terrorism but also poverty, infectious disease and environmental degradation are all problems that are global in scope, posing threats to the security of states and individuals around the world. They can be addressed only through cooperation of equally global dimensions.

Canada is acting on this insight through our continued support of a security agenda that includes measures to prevent violent conflict within states, protect civilians in situations of violent conflict, and increase the

34 Bangladesh, Bolivia, Ethiopia, Ghana, Honduras, Mali, Mozambique, Senegal and Tanzania.CIDA, "New Canadian Investments in Nine Developing Countries," www.acdi-cida.gc.ca/cida_ind.nsf/o/F18796535B8CD71085256C95005E88F1? OpenDocument (accessed 23 October 2003).

35 See Paul Knox, "CIDA gets Rinse and Spin award for this aid announcement," Globe and Mail (15 October 2003), A19. He comments on the phase-out of CIDA funding for India.

36 Foster, "A new kind of 'world power'." 
capacity of states to ensure security for their populations. 0 ur current human security approach emphasizes five core priorities: Public safety, the protection of civilians, conflict prevention, governance and accountability, and peace support operations. ${ }^{37}$

W hile the substance of the argument is compelling, the terminology is proving to be highly problematic. In a world where "security" seems to be overwhelming all other normative frameworks, to treat all these important issues as security concerns has actually come to cloud justifications for action and risks undermining important mechanisms of legal constraint.

A few prominent academics in the U nited States have turned some of the political rhetoric of the US administration, invoking rights to pre-emption and duties to liberate oppressed peoples, into normative claims. Specifically, it has been argued that the constellation of humanitarian crises, terrorism and state failure may amount to a threat to international peace and security, justifying the use of force outside the framework of theun Charter. ${ }^{38} \mathrm{~T}$ his approach effectively draws together heretofore independent normative frameworks, and treats them all as sub-categories of "security." O bviously, one cannot deny that there are situations in which humanitarian disasters, and related state collapse, serve as the breeding ground for various threats to security. The issue is not so much one of causality, but of appropriate response.

O ne of the principal motivations behind the human security agenda was to transform human rights and humanitarian concerns into high politics, in the hopethat they would betreated more seriously. Thisstrategy may have backfired. Given the events of 11 September, "security" seems to have contracted back into its traditional state-centric formulation. Although security should not necessarily imply the use of force, it increasingly does. The human security agenda is being perverted, so that the stress is on "security" and not on humanitarian concerns. G lobal issues cannot all be subsumed within the security framework. C anada must now try to demilitarize someissues, for exampleby re-emphasizing cooperative international criminal law approaches to terrorism.

37 Bill Graham, "Sovereignty, Interdependence and Integration," Address at the 72nd Annual Summer Conference of the Couchiching Institute on Public Affairs, (10 August 2003), webapps.dfait-maeci.gc.ca/minpub/Publication.asp?FileSpec $=$ / Min_Pub_Docs/106360.htm\&Language=E (accessed 21 August 2003).

38 Slaughter, "Fork in the Road," and Buchanan \& Keohane, "The Preventive Use of Force." 
The core elements of the $C$ anadian human security agenda must be re-affirmed. This agenda al ready is an antiterrorism agenda. It is right to draw attention to governanceand humanitarian crises as "root causes" of global terrorism and other threats to international peace and security. ${ }^{39}$ It is also right to argue that there are circumstances where these problems constitute threats to international security and which may require collective military action, but that in many cases they do not. ${ }^{40} \mathrm{C}$ anada could assume a role of leadership in differentiating between these cases. When action is required to address humanitarian concerns, it should bejustified on that basis. When there are threats to security, they must be addressed as such. ${ }^{41}$ In most cases, the primary response will not be the use of force, but rather the building up of economic and social capital, and improvements in governance that $C$ anadian policy has long sought to promote.

The human security agenda may have to be recast to avoid the recent tendency to merge various categories of justification for the use of force into one category of threat prevention. This will require a concerted $C$ anadian effort at norm entrepreneurship. First, $C$ anada must assert the continuing validity of the self-defence and collective security frameworks, while promoting some substantive and institutional adjustments. Second, $C$ anada must actively resist the co-option of the human security agenda by those who would draw upon humanitarian and human rights values to justify the use of force against "new security threats." Third, C anada must continue to work to convince other states that the moment has come to articulate a legal responsibility to protect, where the use of force may be used only as a last resort to prevent or stop humanitarian crises. ${ }^{42}$

Even if pessimists are right and Security C ouncil reform proves elusive, the taskforce recently proposed by Secretary-General Annan can still accomplish something useful. Annan is also asking thetaskforceto

39 See e.g., background papers for the September 2003 conference "Fighting Terrorism for Humanity" www.end-terror.org/background/coverpage.htm (accessed 23 October 2003).

40 See Gareth Evans, "The Responsibility to Protect" Foreign Affairs 81, no. X (XXX 2002), 99.

41 See Richard Falk, "What Future for the Un Charter System of War Prevention?" American Journal of International Law 97, no. X (XXX 2003): 596-597.

42 International Commission on Intervention and State Sovereignty, The Responsibility to Protect (December 2001), www.dfait-maeci.gc.ca/icissciise/report-en.asp (accessed 23 October 2003). 
suggest new standards for the collective authorization of military force. ${ }^{43} \mathrm{H}$ ere is a further opportunity for $\mathrm{C}$ anada. It can lead a frank reappraisal of the current law. It can press for agreement on when support for terrorists exposes a state to defensive military action by threatened states. It can promote new rules that would allow for collective military intervention to avert humanitarian disasters. Some change is urgently needed. Without it, the pressure to weaken international law's limitations on resort to war may prove irresistible. The SecretaryGeneral has specifically linked his new initiative to the $C$ anadian-sponsored report, The Responsibility to Protect. ${ }^{44} \mathrm{C}$ anada is well positioned to expand upon that work by taking an active role in supporting, even guiding, the Secretary-G eneral's initiative. 